\title{
Е.В. Иванцова
}

\section{РЕЧЕВОЕ ПОВЕДЕНИЕ ДИАЛЕКТНОЙ ЯЗЫКОВОЙ ЛИЧНОСТИ В КОНФЛИКТНЫХ СИТУАЦИЯХ ${ }^{1}$}

\begin{abstract}
Статья посвящена коммуникации диалектоносителя в сфере конфликтного взаимодействия. Исследование опирается на материалы идиолектного дискурса сибирской крестьянки. Выявлены виды конфликтов, отмеченные в речевой практике информанта, и особенности этапов развития конфликтного взаимодействия коммуникантов. На основе анализа используемых индивидом тактик и соответствующих им вербальных и невербальных средств реконструируется стратегия поведения языковой личности в конфликтных ситуачиях.

Ключевые слова: диалектная языковая личность, конфликтная ситуация, речевой конфликт, стратегии речевого поведения, тактики речевого поведения, кооперативная языковая личность.
\end{abstract}

\section{Введение}

Исследование речевого общения и речевого поведения носителей языка входит в круг активно изучаемых проблем современного языкознания. Лингвисты обращаются к выявлению принципов и правил речевого поведения, их национального своеобразия, стратегий и тактик в речи коммуникантов, системы речевых жанров и многих смежных с названными вопросов.

Одним из аспектов изучения речевого поведения является анализ общения носителей языка в конфликтных ситуациях. Актуальность работ в этой области на стыке интересов прагмалингвистики, коммуникативной конфликтологии, эколингвистики обусловлена их междисциплинарностью и значимостью развития навыков эффективной речевой коммуникации в современном социуме.

Речевое поведение участников коммуникации в конфликте все чаще привлекает внимание ученых ([1-6] и др.). В связи со сложностями сбора таких данных в спонтанной речи лингвисты опираются главным образом на фрагменты диалогических текстов персонажей из беллетристики и кинофильмов, рассматривая их в качестве художественного аналога естественной речи; в редких случаях используются экспериментальные данные ([7] и полученные методом скрытой фиксации записи разговорных дискурсивных практик [8]). Важной задачей можно считать сбор и анализ матери-

\footnotetext{
${ }^{1}$ Результаты были получены в рамках выполнения государственного задания Минобрнауки России, проект № 0721-2020-0042. This research was supported by the Ministry of Science and Higher Education of the Russian Federation, Project No 0721-2020-0042.
} 
алов реального общения представителей различных страт социума в ситуации речевого конфликта.

В статье эта задача решается с опорой на материалы авторского архива идиолектного дискурса сибирской крестьянки В.П. (1909 г. рождения, русской, малограмотной), собранные методом включения в языковое существование говорящего. В живой устной речи информанта зафиксированы как его непосредственная коммуникация с широким кругом односельчан и родственников, так и отражение этого общения в воспоминаниях индивида. Общий объем дешифрованных аудиозаписей составляет около 10000 страниц печатного текста.

Под конфликтной ситуацией вслед за И.И. Гулаковой понимается ситуация, «в которой происходит коммуникативный конфликт - столкновение двух сторон (участников конфликта) по поводу несоответствия целей, интересов, взглядов, в результате которого одна из сторон сознательно, либо бессознательно, действует в ущерб другой (вербально или невербально), а вторая сторона, осознавая, что указанные действия направлены против ее интересов / целей, предпринимает ответные действия» [3. С. 3-4].

\section{Типы конфликтов в идиолектном дискурсе}

Конфликтологи в зависимости от характера субъекта / субъектов коммуникации выделяют такие разновидности конфликтов, как межличностные, внутриличностные и групповые [9]. Анализ дискурса рассматриваемой языковой личности (далее также ЯЛ) свидетельствует о том, что в нем представлены только межличностные конфликты. Их участниками являются обычно родственники или односельчане; в отдельных эпизодах зафиксирована также коммуникация ЯЛ с посторонними или неизвестными людьми. Обратим внимание на то, что в речевой практике информанта отсутствует конфликтное взаимодействие с должностными лицами.

Отсутствие конфликтов внутриличностного и группового характера, очевидно, можно объяснить спецификой традиционного сельского социума, в котором целостность внутреннего мира входящих в него членов и относительная однородность сообщества определялись силой традиции, единством ценностных установок, во многом сохраняющихся и в наши дни.

Возникновение конфликтов в среде диалектоносителей обусловлено разнообразными причинами, среди которых можно выделить имущественные, поведенческие и мировоззренческие.

Имущественные конфликты связаны с ущемлением имущественных прав индивида. В дискурсивной практике крестьянки отражены такие поводы для возникновения конфликта, как раздел земельных участков между пользователями, присвоение чужого имущества или чужого труда, самовольное распоряжение чужой собственностью. Интересен тот факт, что этот вид конфликтов между сельчанами, как правило, касается не денег, а природных ресурсов (земля) либо собственноручно сделанного или выращенного в своем хозяйстве (дом, скот, овощи и цветы со своего огорода, продукты питания). 
Поведенческие конфликты возникают в связи с нарушением принятых в социуме этических норм, осознаваемых в качестве значимых для личности. Они проявляются вследствие супружеской измены, пьянства, ненормативных отношений между родственниками, соседями и друзьями при несоблюдении законов добропорядочности, взаимоуважения, гостеприимства и др. Отметим, что конфликтогенным фактором могут быть как аморальные поступки, так и речевые действия (неудачная шутка, обидное замечание, бранное слово и т.п.); во многих случаях имеет место и то и другое.

Мировоззренческие конфликты отражают различие взглядов коммуникантов и их отстаивание в процессе общения. Примером такой конфликтной ситуации можно считать речевое взаимодействие двух диалектоносительниц близкого возраста с разногласиями по поводу религиозных убеждений.

Следует заметить, что границы между обозначенными типами не всегда являются четкими: некоторые конфликтные ситуации можно интерпретировать как синтез двух, а иногда и трех разновидностей конфликтов. Так, в эпизоде конфликта, вызванного подменой при продаже качественной вещи на некачественную, нарушение имущественных прав завуалировано обманом как несоблюдением этической нормы. Этическое и мировоззренческое начало сочетаются в конфликте информанта с молодой приезжей соседкой, устраивающей скандал из-за того, что В.П. печет к Пасхе кулич для бывшей жены ее сожителя. Нарушение норм этики проявляется в неуважительном, агрессивном речевом поведении младшего из коммуникантов по отношению к старшему; мировоззренческий компонент отражает несовпадающие взгляды участников конфликта на их право вести себя так или иначе в определенных ситуациях.

Среди выявленных разновидностей конфликта основная доля в идиолектном дискурсе приходится на поведенческие. Имущественные конфликты занимают второе место, а мировоззренческие единичны. Последние, вероятно, редко вербализуются при непосредственном общении рядовых носителей языка. Преобладание конфликтных эпизодов первого типа можно считать закономерным: нормы этики являются базовыми в функционировании любого социума; еще более значимы они в старожильческих селах с высокой плотностью личных контактов и ориентацией ядра таких коллективов на веками поддерживавшиеся традиции.

\section{Речевое поведение языковой личности на этапах конфликтной коммуникации}

Исследователи рассматривают конфликт как коммуникативное событие динамического характера, подразумевающее выделение этапов конфликтной коммуникации ([2, 3, 8, 10, 11] и др.). Они выделяются с разной степенью детализации, однако внимание ученых сосредоточивается в первую очередь на этапе межличностного взаимодействия с момента начальных проявлений противодействия сторон до окончания конфликта. Перифе- 
рийные «околоконфликтные» явления обычно не рассматриваются. В центре такого анализа - стратегии и тактики поведения коммуникантов.

В теории конфликтологии стратегии понимаются как личностные «установки на определенные формы поведения в ситуации конфликта»; как средство реализации стратегий выделяются тактики - «совокупности приемов воздействия на оппонента» [10. С. 238]. Исследователи говорят о разном наборе таких ментальных установок и соотносимых с ними приемов речевого поведения в ситуации конфликта, используя для их обозначения вариативные номинации, но при этом наиболее общим можно считать противопоставление кооперативных и конфронтационных стратегий и тактик. В первом случае участник коммуникации стремится к гармонизации отношений с учетом интересов партнера, во втором - любыми средствами добивается реализации только собственных интересов, что не приводит к восстановлению нормативного общения.

Представляется, что в рамках когнитивно-дискурсивного подхода при исследовании ЯЛ в коммуникативном аспекте

a) наряду с собственно конфликтным взаимодействием коммуникантов должны учитываться предконфликтный и постконфликтный этапы речевого общения;

б) при анализе речевого поведения индивида значима квалификация выявленных в дискурсе индивида тактик, ориентированных на кооперативное / конфронтационное взаимодействие с оппонентом;

в) стратегии говорящего как явление ментального порядка могут быть реконструированы исследователем с учетом преобладания применяемых ЯЛ тактик.

Рассмотрим выявленные эпизоды идиолектного дискурса с учетом этих установок.

1. В дискурсивной практике диалектоносителя можно отметить распространенность ситуаций предотвращения конфликта на предконфликтном этапе, до начала собственно конфликтного взаимодействия коммуникантов.

В одном из эпизодов ЯЛ воздерживается от планируемого поступка, который, по ее предположению, может спровоцировать конфликт. Крестьянка не решается унести на кладбище для обивки столика подаренную подругой клеенку - та может подумать, что подарок не понравился, и обидится: У меня есь клеёнки, много, подарила мне Татьяна Алексевна но'нче бо'ле двух метров, на Восьмое марта принесла. А я хотела её взять - думаю, неудобно: скажет, «Вере не погляну'лась, она на кладбишше сташшыла». Я не понесла. Профилактика конфликта, как можно видеть, заключается в тактике отказа от намерения, которая не содержит вербальной составляющей и отражается при передаче субъектом его внутренней речи.

Отмечено несколько случаев, в которых исследуемая личность применяет тактику отказа от уже осуществляемого действия, оценив его как потенциально конфликтогенное. Оба эпизода связаны с денежными вопросами. В одном из них женщина некоторое время помогает не умеющему 
считать односельчанину пополнять вклад в сберкассе, но потом прекращает оказывать эту помощь: Он же не понима'm мале'нько. Он шимэту [«счёта»] не знат. <..> Он всё на книжку деньги клась как он ко мне приносил. А поцьта рядом была. «Поло'жь мне деньги на книжку!» Ну я думаю: пойду да поло'жу. Потом думаю: како'-нибудь недоразуменье ешо может быть. Он вишь, не понимает. И она [его жена] така' же, не понима'm, дурочка. Аналогичным образом она перестает давать в долг деньги соседке, которая однажды возвращает ей меньшую сумму, чем заняла: Oна приходит ко мне: «Ть мне дай, Вера, пятнадизать рублей». Я ей дала пятнадцать рублей. А она говорит, это... Приходит, деньги получила, приходит: «Я у тебя десять брала?» Я говорю: «Знашь чё? Я тебе больше деньги давать не буду». Я говорю: "Ты вот вишь чё, взяла пятнадияать, а говоришь «десять». Я говорю: «А люди вправду подумают, что как вроде может... да и ты сама поду'машь, что я тебя обманула». Я говорю: «Никого, раз памяти нет, и не даю больше». Она не была, счас ходит занима'т, y меня не берёт. Сообщение об отказе в дружеской услуге (очевидно, оно имело место и в коммуникации с односельчанином) сопровождается говорящим объяснением причин прекращения помощи - возможным недоразумением.

Выделяется также ряд ситуаций, в которых ЯЛ дистанцируется от конфликта между известными ей лицами, используя тактику невмешательства. Крестьянка следует своим принципам поведения, руководствуясь пословицей не наш конь, не наш воз, не нам везти «не следует вмешиваться в чужие дела» из ее цитатного фонда.

Информант не вмешивается, например, в разгорающийся имущественный конфликт односельчан. В отличие от соседки, начавшей принимать активное участие в обсуждении подозреваемых в краже овцы, В.П. отстраняется от обсуждения этой темы, считая обвинение бездоказательным: Овечек гнали, а к Владимиру Прокофьичу забежала чужа' овечка. <..> А он его, видно, приэкономил ли чё ли. <..> А Нюра-то сказала, что он заколол, эта хозяйка барана-то. «Заколол Владимир, гыт, закололи». А е'той-то [соседке] кра'йно надо, она ии'бко така', ей кра'йно надо сказать. Ну я усльхала, а мне-то како' дело? Меня же не задевает, заколол он - не заколол. Не пойманньй - не вор. В другом случае, оказавшись невольным свидетелем враждебного отношения мачехи к маленькому мальчику, крестьянка не заступается за племянника, хотя глубоко сочувствует ребенку: А я легла на это, как её? На скамейку, на лавку-то. Лежу. А пирог с рыбой испекла, с горбушей, эта Вера. [Изображает в лицах усльшанный диалог, меняя просительную, жалобную интонацию на враждебный тон:] «Мама, дай! Мама, дай!» - «Поди ты к чёрту от меня! Поди тыл к чёрту, худой, навязался на меня, чёрт!»-она. Она ду'мат, я сплю лежу, да чё я хоть... пропа'шша [«мёртвая»] ли чё ли? Аүа. Он: «Ма-ама, дай!» Ну чё, ребёнок дак ребёнок и есь. А он в иколу пошёл, ему, наверно, семь лет было. < .. > «Ма-ама, дай! Ма-ама, дай!» Я думаю: үосподи! Ну отре'зала [бы], ну кусочек, они [дети брата] каки'-то ись-то не жа'дны ... 
<...> «Ма-ама, дай! Ма-ама, дай!» - ну как от за' душу тянет. А я лежу да прямо плачу помале'ньку так, про себя. Такое поведение объясняется ею невозможностью изменить ситуацию и убежденностью в том, что вмешательство в жизнь чужой семьи только ухудшит положение сироты: Пана [односельчанка] гыл: "Надо чё-то делать, говорить ей [мачехе] чё ли надо, чё?» Ну, а чё говорить? Наругает тебя, да и всё, вся и разговор.

Типичным для диалектной ЯЛ является также поведение в ситуациях, когда при диалогическом взаимодействии с собеседником говорящий предпочитает умолчать о возникшей у него отрицательной эмоциональной реакции. Такая реакция (недовольство, раздражение, чаще всего - обида) не озвучивается оппоненту «в глаза» даже в мягкой, тактичной форме; субъектом используется тактика умолчания о негативной эмоции. Пережитое эмоциональное состояние отражается в речи информанта только в доверительном общении с близкими, когда контакт с участником диалога уже остается в прошлом.

Показателен пример рассказа о близкой подруге, высказавшей сожаление об участии в чаепитии, поскольку, по ее мнению, оно требует ответного потчевания: Ко мне не стала ходить она, не ходит. Я позвала чай пить раз, она попила пришла, а потом мне говорит: как вроде потчевать ей меня надо - как у меня чай попила, потчевать надо. Дак я разве за этим её звала, чтоб обязательно пойти чай пить? А она говорит: «Ой, я так каюсь-каюсь, что к тебе пошла». А мне не погляну'лось. Так рассердилась на неё. Ну, не ругалась, ничё, так в уме-то думаю: господи, чай попила да кается. Заключительный фрагмент повествования детально обозначает мысли и чувства субъекта (не погляну'лось, рассердилась на неё, в уме-то думаю: господи...), не высказанные собеседнице вслух, и воздержание от проявления агрессии, грубых слов (ну, не ругалась, ничё...). Обратим внимание на маркер думаю, часто встречающийся и в других конфликтных эпизодах при передаче внутренней речи.

Аналогичным образом описывается встреча с другой подругой, которая долго не приходила попроведать больную: Вот Рая у меня не была, это Аксиньина дочка, всё лето, всё лето не была, - а я обиделась на её. <...> Ну я думаю: не идёт - не надо, чё, не идёт дак... Я как болела, ии'бко нога-то у меня, думаю: господи, не идёт ко мне. А теперь она заявля'тся. Мне получше стало, я уж ходить стала. <..> Ну, она заявилась, арбузик принесла мне маленькый, и два яблока. А мне неохота их брать, а как не возьмёшь? В этом случае сохранить с односельчанкой дружеские отношения, наряду с умолчанием об обиде, позволяет акциональная тактика принятия гостинцев как знака дружеского внимания (неохота их брать, a как не возьмёшь?).

К умолчанию женщина прибегает и в случае, когда продавщицы сельского магазина утаивают от ветеранов положенный им продуктовый паек: А я обиделась так вроде, ничё не сказала хоть, а... Физа приходит ко мне, а нам же дают, как ветеранам войны-то это... это, таким, старым-то. А Физа говорит: «А вам там паёк дают». <...> Завтра Коля пошёл-они 
колбасы' прода'ли < ..> а это, мяса уже, гыт, нету. И Таня продавец говорит: «Мясо нехоро'ше было, уже припахывает, и жирно ши'бко». <... А я говорю: «Врёт она. Никого! Себе взяли, да и всё». По сравнению с предыдущими эпизодами комментарий говорящего более грубый (врёт; себе взяли, да и всё), В.П. вполне определенно обвиняет работников магазина в обмане и присвоении продуктов. Тем не менее она не жалуется в официальные инстанции, следуя привычной тактике поведения (A я обиделась так вроде, ничё не сказала хоть, а...).

В дискурсивных материалах отражена также тактика отказа от возражений, при реализации которой несогласие ЯЛ с собеседником переходит в сферу внутренней речи. Реплики, выражающие несогласие, отстаивание своей позиции, как и при переживании обиды, воспроизводятся субъектом постфактум, в разговоре с близкими. Реконструкция того, что не было высказано вслух, также маркируется глаголом думаю: ...Шура Викторова: «Я бы давно...»вот эта юбчонка така' ху'денька Еленина [у меня] была, она гыт: «Я бы давно её выкинула, по'д берег ли кудыл' либо сожала ли бы, я всё там приеду, дак... к Гале [дочери], да всё жсу, всё жгу...» Я думаю: «Тебе чё надо-то?» Ничё не со'дит, и никого не де'лат и... и сама ничё. <...> ...приходила ко мне, давно уж: «Тыл, Вера, купи от этот, пла'тельный... шифонер купи, пла'тельныий шкаф купи, купи стол ку'хольный...» А я думаю: «Tы-то пошто' не покупа'шь? Ты же дочь моя [по возрасту], пошто' не покупа'шь-то ничё?».

Как можно видеть, ЯЛ последовательно избегает и поступков и высказываний, которые могли бы запустить механизм конфликтного взаимодействия. К ним относятся такие тактики, как отказ от потенциально конфликтогенных намерений и действий, невмешательство в конфликты между другими лицами, умолчание говорящего о негативной эмоции в диалоге с собеседником, отказ от речевого противодействия в случае несогласия с ним, принятие подарков в подтверждение дружеских отношений. На этом этапе речевого взаимодействия выявленные тактики редко подкреплены вербальными средствами: среди всех перечисленных лишь решение об отказе от ранее осуществлявшейся услуги (дача взаймы небольших сумм, помощь в перечислении денег в сберкассе) озвучивается информантом; редки и тактики, подкрепляемые акционально (принятие гостинцев). В остальных случаях только с опорой на рассказ о прошедшем событии можно реконструировать потенциально возможный деструктивный характер реплик и/или поступков индивида (отраженный при передаче внутренней речи) и сопоставить его с выбором ЯЛ иного, кооперативного способа взаимодействия с оппонентом в реальной коммуникации. Конфронтационной среди выявленных тактик можно считать только частный случай отказа от осуществляемого действия - прекращение дружеской услуги, поскольку такое действие ущемляет интересы партнера. Однако отметим, что отказ смягчается объяснением причин прекращения помощи.

2. В дискурсе исследуемой ЯЛ также представлены эпизоды, отражающие ее непосредственное речевое взаимодействие с коммуникантами на этапе открытого конфликта. 
Д.В. Иванова отмечает: «Как правило, в конфликтных ситуациях задействованы два участника, один из которых ведет себя более агрессивно, нападает, а второй пытается сгладить ситуацию, погасить агрессию собеседника, выйти из ссоры, стараясь при этом, чтобы его собственные речевые действия не были агрессивны» [12. С. 226]. В.П. крайне редко является инициатором конфликта; обычно она вступает в диалог с его зачинщиком, используя богатый спектр смягчающих агрессию кооперативных тактик.

В отличие от предконфликтного этапа коммуникации, на котором тактики слабо вербализуются, на этапе открытого конфликта (по В.Д. Третьяковой, в коммуникативной фазе его развития [2]) они регулярно поддерживаются вербальными и невербальными средствами.

Широко применяет информант тактику объяснения. По мнению Д.В. Ивановой, «спокойные доброжелательные ответы, подробное объяснение своей позиции и своего взгляда на ситуацию способствуют эффективному общению, а в конфликтных ситуациях помогают донести до собеседника свою точку зрения и улучшить коммуникативную тональность общения» [4. С. 12]. Исследование фрагментов речевой практики сибирской крестьянки показывает, что в составе приводимых аргументов ЯЛ не только называет факты, дающие собеседнику информацию о мотивах своих поступков в той или иной ситуации, но и в некоторых случаях отстаивает право поступать в соответствии со своими взглядами и убеждениями. Так, накануне Пасхи крестьянка стряпает куличи и хочет кра'дучи передать гостинец своей бывшей соседке, которая после развода с мужем переехала в другое село. Однако тайну сохранить не удается, и новая сожительница соседа устраивает скандал, с грубой бранью обвиняя пожилую женщину в угодничестве: Она пришла, как давай материться! < .. > «Лёша меня [ругал], что ты па'ски стря'пашь там да ... она продавцом рабо'тат, дак вы ей жопу лижете» - вот так вот давай на меня. В.П. отражает нападки, объясняя, что посылка кулича - знак благодарности женщине, которая поддерживала с ней добрососедские отношения: «Для меня Таня хоро'ша, я её век не забуду. < ..> Бежит: «Чё у тебя, тётя Вера, есь огурчи'шки мале'нько, давай!» < ..> увезёт продас. И деньги ташшыт. < ..> Ну, выручала она меня». Она говорит также о том, что межличностные негативные отношения не повод их распространения на других людей (Я говорю: «Bот у меня Степан [муж] ушёл, и ходили они там [к нему], хо'дют, дак я чё, буду сердиться на всех, что "вы не принимайте Степана там, вы Маньку не принимайте та'мо-ка»? Я, говорю, при чём?»), и подчеркивает, что посторонние не имеют права диктовать, как ей поступать (Я говорю: «Зря я не спросила вас [ирон.], надо было потти' вас спросить, можно ли нет состряпать па'ску?»).

Более редки иные тактики. В ситуации, когда В.П. прячет в своем доме соседку с детьми от угрожающего оружием пьяного мужа, на грубое требование открыть дверь ( $А$ у меня ворота'-то на зало'мке уж, а он сту'кат в окошко: «Сука!» - на меня), она прибегает к лести (выдавая желаемое за действительное), а также использует просьбу и уговаривание, подчерки- 
вая свой возрастной статус, требующий уважительного отношения: Я говорю: «Не открою я тебе, Лёня», - а его уговариваю, говорю. - Ты хороший сосед, ну, говорю, ты меня не беспокой, ты чё меня беспокоишь, ста'реньку, говорю, таку'?»-ему.

Как можно видеть, в рассмотренных примерах информант как бы не замечает речевой агрессии другой стороны конфликтного взаимодействия. Вместо зеркального отражения чужих провокационных тактик и языковых средств (угрозы, обвинения и требования, брань и крики) ЯЛ опирается на кооперативные тактики объяснения, лести, просьбы, уговоров. Противодействие зачинщику конфликта осуществляется информантом в спокойном тоне, при воздействии на собеседника он может прибегнуть к просительной интонации. При выборе лексических средств говорящий отдает предпочтение безоценочной апеллятивной лексике, в тактике лести отмечен маркер позитивной оценки собеседника (ты хороший сосед). Для обращения к оппонентам используются полные или нейтральные неполные имена (Лексе'й, Аксинья, Лёня).

Конфронтационные тактики также используются ЯЛ при конфликтном взаимодействии. Преобладающей среди них можно считать упрек. Он относится к конфронтационным приемам воздействия: целью говорящего в этом случае является «выражение неудовольствия, неодобрения, обвинение» [13. С. 836], которые могут быть восприняты в качестве конфликтогенов. Упрекая, носитель традиционной народно-речевой культуры делает акцент на необходимости следования моральным нормам, нарушаемым участниками конфликта.

Чаще всего при генерировании упрека диалектоносительница опирается на базовые для обыденной морали понятия внутренних регуляторов поведения в соответствии с системой ценностей социума, выработанной в течение многих столетий. Одно из таких понятий - стыд. Нередко упрек вербализуется в клишированном высказывании как тебе не стыдно. Оно звучит в ответ на грязную брань молодого мужчины в ее адрес ( « $\bar{*}^{* * *} ю^{\prime} 2 a$, открывай, проститутка!» - на меня. Я говорю: «И не стыдно тебе, Лексе'й? - говорю, - как тебе не стылно, ты чё говоришь-то?»); аналогичным образом информант реагирует на слова родственника, который хочет выпить спиртного (Кружечку надо выпить, да идти. - Как не стылно, ейбогу!), неподобающий внешний вид односельчанина (Я говорю: «Не ходи, как тебе не стыдно в таком... с такими рваными итанами, по улице-то идти, надо же?») и т.д. В дискурсе встречается, кроме того, единичное упоминание такой нормы отношений между людьми, как милосердие: $E p$ маков, выкопал у меня два ряда' [картошки]. Две сотки, о'бшэм. А я говорю: «От дак милосердие, - говорю. - Старым людя'м все говорят помогать да всё, а вы,, - говорю, - после'дне у меня итобра'ли».

Упрек в отсутствии совести воспринимается говорящим, очевидно, как наиболее жесткий коммуникативный ход и редко озвучивается при личном контакте. Показательно при этом использование приемов смягчения осудительной коннотации лексемы бессовестный. Так, в присутствии конкретного человека информант может выразить негативную оценку его по- 
ступка обобщенно, как бы в адрес неопределенного множества лиц (прием генерализации): Галька-пьянчужка [вырвала в огороде В.П. тюльпаны. Далее передает диалог с ней:] «А хочешь, я тебе скажу, кто у тебя вырвал?» Я говорю: «О-ой! Неужели нет? Хочу!» - «Я» - гыт. < ... $>$ Я говорю: “Бессо'вестны-то каки'», - говорю. Аүа. «Ну не ругайся, не ругайся». В качестве другого приема используется эвфемизация. В рассказе о залезших в огород воришках можно видеть, как изначально предполагавшаяся реплика В.П. с осуждающей оценкой меняется на высказывание с предположением: $A$ этот залазит в огород. <..> А я-то лежу на этой, на раскладушке, а он-то [сын] тут на койке. «Мама, гыт, идут! Идут, гыт»». А я тапочки не могу найти, - я бы хыть это, постыдила бы так, вышла, скажу: «Кудын' вы лезете, бессо'вестны?» Думаю, схожу - тапочки не могу найти. <...> «Выз заблудились, наверно, кудыл' зашли?»-я не заругалась, ничё, так это: «Заблудились, гыт? Выкуды' залезли, гыт?» Они побежали. И вот это, с тех пор не лазили. Кроме замены грубого лезете на заблудились, позволяющее ворам «сохранить лицо», опускается и прилагательное бессовестные.

Эллиптизация названия действия или признака коммуниканта, вызвавшего недовольство говорящего, встречается при смягчении упрека и во многих других случаях: A теперь знашь каки' детки, Катя? Не дай бог же! От у их тут койка стоит, а тут это, стол. А он [мальчик] на стол заскочил и, гляжу, на кровать. А ему было - ну, лет восемь, девять ли, уж такой. Я ему: "О'споди, Дима, ты чё де'лашь?» Я говорю: “Ты пошто' так, койка заправлена» - ну скака'т туды' прямо безо всяких! Систематически привлекается с этой же целью и генерализация: [пьяному мужчине:] $T$ bl куды' идёшь-то? Пошто' таки'-то? Для сглаживания упрека может использоваться также шутливая интонация: $A$ я говорю [почтальону, которая, не застав хозяйку дома, велела ей самой прийти за пенсией на почту]: "Дак а вот у вас если денег не бува'т, если вы не прино'сите пенсию $<\ldots>$ дак вам ничё это, та'мо-ка можно, а нам нельзя?» - вроде шуткой, а сама в обиду говорю.

Уступают упреку по распространенности другие конфронтационные тактики, используемые информантом в тех случаях, когда кооперативные тактики не дают должного эффекта. Угрозы и приказ отмечены, например, в конфликтном взаимодействии с непослушным мальчиком, оставленным на попечение женщины родственниками: Я пошла и звала-звала, звала-звала его, он ни за что не идёт. Я говорю: «Я тебя на замок закрою и оставлю сейчас». < ...> «Ты пойдём, - говорю, - а то папа приедет, я нажалуюсь папе и маме расскажу всё, что ты меня ниско'ль не слу'шашь». <...> Потом я на него как крикнула! Я говорю: "Что ты де'лашь? Айда'!» За руку взяла. А он: «Я сам наемся и пойду к тёте Ане на работу». Я грю: «Спаси Бог!». Когда речевое воздействие не приводит к желаемому результату, В.П. подкрепляет тактику приказа (Айда'!) акционально (за руку взяла) и меняет интонацию увещевания на повышенный тон (как крикнула!). Показательно, что использование приказа отмечено по 
отношению к ребенку: в адрес взрослых эта тактика обычно заменяется просьбой (что совпадает с выводами О.А. Казаковой [14. С. 65]).

Разновидностью угрозы можно считать тактику апелляции к властным структурам, которая встречается в конфликтах с односельчанами. Так, при краже ведер из ее усадьбы крестьянка делает попытку вернуть свое имущество у воровки, угрожая, что иначе заявит о ее поступке в сельсовет: «Принесу, принесу в понедельник». От понедельник прошёл, авто'рник - и опе'ть понедельник. Я взяла да это... записку пишу: «Галя! Без греха отдай вёдра. Я пока'месь в сельсовет не обратилась, никуды', - говорю. - Я ии'бко никому не говорю... - а сама всё равно всем говорю. - Я, - говорю, - никому не разглашаю ши'бко, ничё - ну тут без сельсовета, говорю, не обойдётся, я должна пойти в сельсовет». Я говорю: «Принеси без греха!».

В конфликтном диалоге у диалектоносительницы отмечено и декларативное отрицание тезиса оппонента. Данная тактика используется, когда положение дел для ЯЛ настолько очевидно, что, по ее мнению, не требует объяснений и доказательств. Отрицание такого рода встречается, например, в эпизоде конфликта с односельчанкой во время работы на поле: А тут одна старуха была <...> А вязали-то со снопа. А там за сноп... фи'га получишь. <...> Овёс-то коро-отенькый тут остался! на вя'зки [«жгуты из соломы для связывания снопов»] делать. Она: «Это тыл, Вера, у меня вязки украла!» Я говорю: «Да ты чё? Я пошто' буду у тебя брать?» Ну, молчу, чё она... Она така' ругательница была - я молчу. < ..> А потом, кода' стала: «Ой, Вера, ты меня прости. Это они тут от валялись под снопом, а я не видала». Я говорю: «Ну дак ты пошто' на меня-то говоришь? Неужели пойду вязки у тебя брать?» Не считая нужным оправдываться, В.П. реагирует на обвинение только риторическими вопросами: Я пошто' буду у тебя брать?; Неужели пойду вязки у тебя брать? За этими репликами стоит и отсутствие для крестьянки необходимости в вещи, которую она способна сделать за секунды сама, и усвоенная с детства заповедь «не брать чужого».

Аналогичным является ее речевое поведение в эпизоде мировоззренческого конфликта: Вот у Поли сестра четырнадцатого году, ну она сильно регио'зна, в иее'рькву ходит чуть не ка'эный день, у ей забота одна - в ие'рькву притти', - она себя шшыта'т святой. Я картошки копала, она говорит: «Ну чё, я, как вроде, свята'». Я говорю: «Ну кака' же ты свята'то?». Батюшка [о священнике] - «Бог» она называ'т. Я говорю: «Ну батюшка - не Бог же!» < ...> Ну если она в иее'рькву ходит, молится - ну не свята' же она? Кака' она свята'? Я говорю: «Ну! Это неправда, говорю. Какой батюшка Бог?» Ой, она как вскочила на меня, По'лина сестра <...>. [Так это вы с ней поссорились?] Нет, не поссорились, в обшэм, перебросились словами. Не признавая религиозную участницу спора святой, а священника Богом, информант так же, как в ситуации с ложным обвинением, ограничивается лаконичным отрицанием (это неправда) и риторическими вопросами (Ну батюшка - какой Бог? Ну какой Бог батюшка? Ну если она в иче'рькву ходит, молится - ну не свята' же она? Кака' она свята'?). 
Оба эпизода, кроме риторических вопросов, объединяют также категоричность интонаций говорящего, отсутствие аргументов и приемов смягчения конфронтации.

Близкой к тактике декларативного отрицания по использованию языковых средств является тактика категорического отказа. Кроме риторической фигуры утверждения в форме вопроса, ее маркерами являются лексемы нет /нету, ничё, никого (в значении «ничего»), часто повторяющиеся многократно: "Мне надо выпить, хоть гушиу давай каку'-нибудь». Я говорю: «Вот нет у меня!» - «Ну это... хоть деколо'н давай!» Я говорю: «А я де возьму-то его? < ... > Я говорю: «Никого у меня нету. Ничё нету».

Материал, таким образом, показывает, что в составе конфронтационных тактик ЯЛ встречается в первую очередь упрек, значительно реже - угроза (в том числе - через апелляцию к власти), приказ, декларативное отрицание при несогласии с оппонентом, категорический отказ. При их реализации говорящим используются неодобрительный, раздраженный тон, отрывистость произношения, иногда ироническая интонация, отдельные клишированные конструкции (как тебе не стыдно, пошто' таки'), увеличивается доля императивов, сокращается объем высказываний. Вместе с тем обращает на себя внимание частое смягчение средств, которые могут восприниматься собеседником как конфликтогенные, посредством эвфемизмов, эллипсиса негативных номинаций, шутки, замены прямой критики собеседника на косвенную через деперсонализированные, обобщенные критические суждения.

В развернутых конфликтных диалогах для исследуемой ЯЛ при речевом взаимодействии характерно сочетание различных тактик.

Показателен в этом отношении диалог В.П. с родственником средних лет, который настойчиво просит у нее взаймы денег на спиртное. Начало конфликта отражает открытое противоборство субъектов. Конфликтогеном выступает требование мужчины (Bbl дайте!). Собеседница не одобряет его пристрастия к алкоголю и использует все возможные средства, чтобы коммуникант отказался от своего намерения. Ее речевая партия в диалоге включает многократный категорический отказ в просьбе (He $\partial \mathrm{an}$, никого не дам, у меня никого нет. Никого не дам). Используется нетипичная для информанта резкая негативная оценка поведения собеседника при очном общении (Совсем... совсем сдурели; Чё, с ума сошёл нагото'во, ли чё ли?). Женщина широко привлекает разнообразные виды упреков. Она укоряет племянника в том, что он мало занимается хозяйством (Hy $u$ правда: ты подумай сам, ни черта' не де'лате, абсолютно ничё не де'лате! С домом никого не де'лате, ни с баней, ничё! Взял бы баню да склал бы!), не жалеет жену (тебе ничё не жалко, и не жарко, и не холодно) и наносит ущерб семейному бюджету (Ешо деньги на вино просит! А каки' деньги, кода' на хлеб нету денег? Tbl ись-то всё равно ешь). Заметим, что обвинения в безделье и больших расходах на еду в пылу полемики сильно преувеличиваются: в других ситуациях она характеризует родственника иначе. В качестве наиболее «сильной» тактики озвучивается ультиматив- 
ная угроза разрыва семейных отношений: $и$ без вас обойдусь и прожсиу как-нибудь и... не ходите больше ко мне, вот так.

ЯЛ при этом опирается на конфликтогенные средства всех ярусов языковой системы. Не сдерживая эмоций, она ведет диалог раздраженным тоном; реплики отрывисты, используются иронические эхо-повторы слов собеседника, который пытается шутить: H. Видишь, жарко, [в]он споте'л. - В.П. «Споте'л»! < ..> Никого не дам. - Н. Я же вечером отдам. В.П. «Отдам!» Да был отдам, да по'мер. - Н. Ну пошто' по'мер-то? Я не буду помира'ть. - В.П. «Не буду помира'ть». Помрёте! В речи присутствует пейоративная лексика и фразеология (сдурел; с ума сошёл; тебе... не жарко и не холодно), в том числе бранные фразеологизмы (Да ну тебя!; Да ну вас к чёрту! К чёрту тебя), употребляемые крестьянкой только в ситуациях крайнего раздражения, а также паремия был отдам, да по'мер со значением отказа на просьбу дать что-либо взаймы.

Привлекает она и конструктивные тактики речевого взаимодействия. В первую очередь это разнообразные приемы воздействия, в которых переплетаются убеждение (где говорящий опирается прежде всего на логические доводы) и уговаривание (с воздействием преимущественно на эмоции адресата) [15]. В их числе - аргумент, подразумевающий личную заинтересованность оппонента в сохранении своего здоровья и жизни (Да вы же погиба'те [от пьянства]), подчеркивание снижения социального статуса пьющего человека (Как Саша Пега'сьев, ешо хуже будете!), взывание к чувствам - попытка вызвать жалость к состоянию больной жены (и её жалко ить она человек! То больна' ешо!) и к ее собственному состоянию как близкой родственницы (Хыть бы меня пожалел уж, ты её [жену] не слу'шашь. Я же тебе как мать родна', я же вас - сколько я вам помогала.. < ..> Уж и глаза не глядят, и руки не движутся, тянет руки все...). Изначальная резкость отказа смягчается вымышленными причинами ( $A$ y меня отку'дова деньги? Tы сам видел, что я Поле итдала' все деньги), в том числе - для большей убедительности - ссылкой на свидетелей (Не дам никого, у меня нету, я вот Лёньке итдала' - вот свидетель, Катя. И Илья взял бутьлку, Pae). Звучит призыв к преодолению пагубной привычки, также смягчаемый модальным словом поди: Ну, поди, можно бросить-то это дело?

При реализации кооперативных тактик, которые в первой половине диалога чередуются с конфронтационными, а к его концу начинают преобладать, информант опирается на безоценочные лексические единицы; эмоциональность синтаксиса сохраняется, но речь становится более плавной, появляются сравнительные конструкции, исчезают эхо-повторы, интонации иронии и раздражения. Отметим также используемый на протяжении всей ссоры прием смягчения негативных оценок в адрес виновника конфликта через генерализацию с заменой личного местоимения mbl на обобщенное вы и глаголов единственного числа на множественное (да вы же погиба'те; совсем сдурели; ни черта' не де'лате).

Речевой конфликт разрешается благодаря акциональной уступке, к которой прибегает В.П. Она не дает просителю требуемых денег, но позволя- 
ет ему выпить домашней браги. Уступка сопровождается определенными «воспитательными» условиями: Вон, бражо'нку выпей мале'нько, ешо в бутылке, и всё. <..> Если не будешь вино покупать - дам брагу, а будешь - ничё не дам. <..> [наливает стакан] Пей, и больше не пей! И не проси у меня никаки' деньги, никого не проси. Набор тактик и принципы их комбинирования во многом сходны с выделенными А.В. Масловой при анализе подробного рассказа этого информанта о другом конфликтном эпизоде по поводу кражи ведер [16].

Как уже говорилось выше, для исследуемой ЯЛ нетипична роль инициатора речевого конфликта. Тем не менее конфликтные ситуации, в которых она выступает как зачинщик, тоже имеют место в дискурсе индивида.

Один из таких эпизодов отражает ссору диалектоносительницы с подругой. Она наряду с другими гостями пригласила на именины односельчанку, с которой дружила много лет, приготовила ее любимые кушанья (А я для её старалась всё, я ши'бко старалась, ей-боүу, от ей-боүу! Думаю, всё получше иставля'ла всё, чё она любит, вку'сненько, све'же всё), а та пришла только на следующий день. Огорчение хозяйки в связи с тем, что потчевать было уже почти нечем, спонтанно вербализовалось в упреке с беззлобным, полушутливым использованием бранного слова ( $H y, n^{* * * a}$ же Поля тыл, - говорю, - тыл! Не могла прийти-то вчара'?» Oт так от взяла да и сказала). Обида подруги («Ы! Oй! O!» - от э'дак она как заплачет, заревёт, бежать...) вызвала мгновенное извинение (Я за ей: "Да Поля, да ты чё? Ну прости меня, ну чё, вырвалось у меня так да всё... проcmu»), тем не менее общение между ними надолго прекратилось.

Данный конфликт можно рассматривать как коммуникативную неудачу. Сложно однозначно сказать, что именно так сильно задело Полю упрек в том, что не пришла вовремя, или сниженность формы выражения этого упрека. Реакция хорошо знакомой гостьи оказалась для хозяйки неожиданной и долго подвергалась рефлексии: $H y$, это бы не вхо'жи были, сроду перво ба, ну, на вас бы [обращаясь к диалектологам] я могла сказать [и вызвать обиду]. Ну, чё-нибудь, ну, тут-то?.. Ну, я прям не подумала. Она не считала свою вину значительной, поскольку обсценная лексема была употреблена не со зла, однако дружеские отношения восстанавливались более полугода.

Рассмотренный эпизод коммуникативной неудачи можно считать нехарактерным для данной ЯЛ, которой свойственны тактичность общения, следование нормам речевого этикета и хорошее знание психологических особенностей людей из ее близкого окружения. Однако в дискурсивной практике крестьянки выявлена своеобразная серия конфликтных эпизодов, где она выступает инициатором конфронтационного взаимодействия вполне осознанно.

Эти эпизоды связаны с ситуацией измены и ухода из семьи любимого мужа. По этическим причинам воспоминания информанта о них приводятся предельно кратко. Отметим лишь, что оскорбленной женщиной использовались как акциональные, так и вербальные деструктивные тактики по- 
ведения - от тайной мести изменнику ( $А$ он уж стал ходить, бегать $к$ этой, к Маньке-то. Я украла у него ве'лик-то. Уташшыла, да к Сергею Прокофьичу на вышку [«чердак»] запихала. <...> И он меня добивался, добивался, я так ему и не сказала [где велосипед]) и «разборок» с соперницей (К которой Степан-то ушёл - я с ей дралась даже. Дрались мьл. Аүа. Я подошла да палочку таку' взяла небольшу', таку' то'лсту. <..> И пришла да окошко выбила. И стою. <..> Она выскочила, и нечего ей схватить-то - она палку таку' то-олсту, дрова лежали, она поймала да за мной. Ну этой палкой разе можно ударить? Её надо поднять да всё, она здоро'ва была - ну как я же, обо'е одина'ковы. Ну она моложе меня намного. А я-то этой палочкой: раз-раз-раз-раз!) до ее оскорбления (Mbl поехали со Степаном, а куды' поехали - не знаю. А она идёт, а мы её догнали. <...> А он уж с ей таскался. А я это... догнали её, мале'нько стали обгонять-то... <..> А я: «Куть-куть-куть-куть-куть!! на её. - Сучка, сучка!» И он ничё мне не сказал) и декларации разрыва отношений с мужем (Он придёт но'ччу там-ка, налюбуется да придёт, а я: «Уходи к чёрту совсем туды', иди!» Я говорю: «Кусок в пепел помочу, да может, слаше мёду съем, на чёрта мне твоё от это всё?»).

Хотя формально в эпизодах этой тематики информант выступает инициатором агрессивного взаимодействия, истоки конфликта восходят к поступкам других лиц. Поведение В.П. по отношению к супругу и сопернице оправданно в ее представлении: истинные виновники конфликта разрушают семейные связи - одну из главных общечеловеческих ценностей, имеющих особую значимость в традиционной культуре. Оправданно такое поведение и в коллективном моральном кодексе сельчан: в числе прочих конфронтационных действий рассказчицей упомянута распространенная в сельском социуме практика разбивания оконных стекол в доме любовницы мужа. Битье окон, очевидно, не только преследует цель нанесения ущерба из ревности, но и выполняет символическую функцию разрушения преступной связи. Эти эпизоды занимают особое место в дискурсивной практике ЯЛ, являясь исключением из характерных для крестьянки правил речевого общения.

3. Этап постконфликтного взаимодействия довольно слабо представлен в речевых свидетельствах информанта. Тем не менее материалы показывают, что в ситуациях, где причиной конфликта было агрессивное поведение (в том числе речевое) односельчан и родственников, после его завершения коммуниканты возвращаются к нормативному повседневному общению. Приведем примеры из нескольких эпизодов. Хотя «за глаза» В.П. квалифицирует действия ломившегося в дом пьяного мужчины с оружием как фулюга'нство и считает, что хулиган должен был попросить прощения за свое поведение, на следующий день они здороваются как обычно. При этом она не напоминает соседу о вчерашнем происшествии и воздерживается от упрека: Дак не извинился! От какой! Наза'втре шёл,

\footnotetext{
${ }^{1}$ Диалектное междометие, используемое для подзывания собаки.
} 
едет: «Здравствуйте!» Я говорю: «Здравствуй». В другом эпизоде его сожительница, устроившая скандал из-за состряпанного В.П. кулича, вскоре приходит к ней с просьбой, и та по-соседски ей не отказывает: И она тут наревела-накриче'ла [на меня], гляжу - она идёт ко мне опе'ть. «Уж ты меня извини, баба Вера, ты меня извини, я это, пришла бутылочку [спиртного] у тебя попросить». А я ей дала бутылку. Диалектоносительница не порывает отношений ни с девушкой, без спроса сорвавшей у нее в огороде тюльпаны, ни с женщиной, укравшей с ее двора вёдра. После примирения с подругой, обидевшейся на упрек с грубым словом, между ними было восстановлено прежнее дружеское общение. Выделить на этом этапе специфические тактики речевого поведения не представляется возможным: остаточные явления недавнего конфликта в межличностном взаимодействии не наблюдаются. Только конфликт с мужем и «разлучницей», к которой он ушел из семьи, не завершается прощением и примирением; эти люди исключаются языковой личностью из круга коммуникации навсегда.

\section{Выводы}

Материалы идиолектного дискурса позволяют сделать предварительные выводы о речевом поведении диалектной ЯЛ в конфликтных ситуациях. Установлено, что у информанта зафиксированы только межличностные конфликты в бытовой сфере. Наиболее частотны поведенческие конфликты или конфликты с поведенческой составляющей, что свидетельствует об ориентации на этические нормы как мотивационной доминанте личности.

В дискурсивной практике индивида отмечены эпизоды разного порядка - c кооперативной и конфронтационной линией коммуникации и соответствующими им тактиками. Однако кооперативное начало в общении диалектоносительницы явно преобладает. В предконфликтных ситуациях, которые несут в себе опасность перерастания в открытое противоборство, а также на этапе собственно коммуникативного конфликта в ее поведении доминирует кооперативная стратегия, направленная на предотвращение конфронтации с собеседниками, ее сглаживание и примирение сторон. Инициирование конфликта и агрессивное противодействие коммуниканту наблюдается только в ограниченной группе эпизодов, связанных с распадом семьи по вине мужа. Согласно классификации Е.А. Ничипорович [17] исследуемый индивид является представителем ЯЛ кооперативного типа.

Можно предполагать, что выявленные особенности речевого поведения крестьянки базируются на установках традиционной народной культуры. Анализируя бытование традиционных сообществ, в том числе сельских, историки и антропологи указывают на то, что конфликтные ситуации ставят под угрозу социальные связи и сохранность структуры социума [18]. Вследствие этого и община в целом, и ее члены заинтересованы в примирении противоборствующих сторон конфликта [19. С. 170]. Кооперативная речевая стратегия способствует поддержанию дружелюбных отношений, значимых для обеспечения безопасного и комфортного сосуществования в 
деревенском сообществе. Ориентация на данную стратегию поддерживается и индивидуальными качествами исследуемой языковой личности, которой присущи доброжелательность, толерантность, сдержанность в проявлении эмоций, следование базовым нормам этики и этикета.

\section{Лuтература}

1. Муравьева Н.В. Речевые механизмы коммуникативных конфликтов: автореф. дис. ... д-ра филол. наук. М., 2002. 50 с.

2. Третьякова В.С. Речевой конфликт и гармонизация общения: дис. ... д-ра филол. наук. Екатеринбург, 2003. $301 \mathrm{c.}$

3. Гулакова И.И. Коммуникативные стратегии и тактики речевого поведения в конфликтной ситуации общения: автореф. дис. .... канд. филол. наук. Орел, 2004. 19 с.

4. Иванова Д.В. Речевые способы преодоления конфликта (на материале русского и английского языков): автореф. дис. ... канд. филол. наук. Саратов, 2010. 21 с.

5. Ершова B.E. Речевое взаимодействие в условиях конфликта: ситуационный подход (на материале ток-шоу и теледебатов): автореф. дис. ... канд. филол. наук. Томск, 2013. $18 \mathrm{c}$.

6. Белова E.B. Речевые маркеры бытового конфликта // Вестник Тверского государственного университета. Серия: Филология. 2017. № 2. С. 157-161.

7. Комалова Л.Р. Реконструкция образа предконфликтной ситуации на основе речевой продукции коммуникантов // Этнопсихолингвистика. 2018. № 1. С. 126-140.

8. Черных 3.B. Композиционные элементы конфликтных эпизодов в студенческой коммуникации // Сибирский филологический журнал. 2016. № 2. С. 177-187.

9. Шейнов В.П. Управление конфликтами. URL: https:/bookap.info/book/sheynov_ upravlenie_konfliktami/gl55.shtm (дата обращения: 11.03.2020).

10. Аниупов А.Я., Шипилов А.И. Конфликтология: учеб. для вузов. М. : ЮНИТИ, 2000. 551 c. URL: http://sdo.mgaps.ru/books/KP1/M11/file/1.pdf_(дата_обращения: 25.02.2020).

11. Кашапов M.M. Теория и практика решения конфликтных ситуаций: учеб. пособие. Москва ; Ярославль : Ремдер, 2003. 183 с.

12. Иванова Д.В. Прием объяснения в ситуации преодоления конфликта: эколингвистический аспект // Экология языка и коммуникативная практика. 2015. № 1. С. 225-231.

13. Ожегов С.И., Шведова Н.Ю. Толковый словарь русского языка. 4-е изд., доп. М. : ИНФОТЕХ, 2009. 944 c.

14. Казакова О.А. Диалектная языковая личность диалектоносителя в жанровом аспекте. Томск : Изд-во ТПУ, 2007. 200 с.

15. Горикова К.Ю. Речевые жанры аргументативного дискурса: убеждение и уговаривание // Известия Волгоградского государственного педагогического университета. 2018. № 5 (128). С. 108-116.

16. Маслова А.B. Реализация установки на гармоничное общение в речи диалектной языковой личности // Экология языка и коммуникативная практика. 2014. № 1. С. 143-149.

17. Ничипорович E.A. Кооперативная языковая личность в открытом коммуникативном эпизоде : автореф. дис. ... канд. филол. наук. М., 1998. 22 с.

18. Кушкова А.Н. Крестьянская ссора: опыт изучения деревенской повседневности: по материалам европейской части России второй половины XIX - начала XX века. СПб. : Изд-во Европейского ун-та, 2016. 318 с. (Studia Ethnologica; вып. 13).

19. Рулан Н. Юридическая антропология : учеб. для вузов / ред. В.С. Нерсесянц. M. : Норма, 2000. 312 c. 
The Speech Behaviour of a Dialect Language Personality in Conflict Situations

Vestnik Tomskogo gosudarstvennogo universiteta. Filologiya - Tomsk State University Journal of Philology. 2020. 66. 26-44. DOI: 10.17223/19986645/66/2

Ekaterina $V$. Ivantsova, Tomsk State University (Tomsk, Russian Federation). E-mail: ekivancova@yandex.ru

Keywords: dialect language personality, conflict situation, speech conflict, strategies of speech behaviour, tactics of speech behaviour, cooperative language personality.

This research was supported by the Ministry of Science and Higher Education of the Russian Federation, Project No 0721-2020-0042.

The article examines the speech communication of a dialect speaker in the field of conflict interaction. The analysis is based on the materials of the discourse of a Siberian peasant woman. She is Russian, semi-literate, born in 1909. The study showed that her speech practice contains interpersonal conflicts in the absence of intrapersonal and group conflicts. Behavioural, property, and ideological conflicts are identified with the predominance of behavioural ones. The stages of conflict communication and the tactics the speaker used are considered. The tactics mainly focus on cooperative/confrontational interaction with the opponent. At the pre-conflict stage, the speaker consistently avoids actions and statements that may cause conflict. For this purpose, she uses the tactics of refusing from potentially conflicting intentions and actions, non-interfering in conflicts between other persons, keeping silent about negative emotions in dialogues with interlocutors, refusing from verbal countering in case of disagreement with interlocutors, accepting gifts in confirmation of friendly relations; most of the tactics are cooperative. At this stage, the tactics are rarely supported by words. At the stage of open conflict, when direct speech interaction with interlocutors takes place, the speaker is extremely rarely the initiator (the exception is a series of episodes related to the situation of her husband's betrayal and his leaving the family). When communicating with the aggressor, she relies on both cooperative and confrontational tactics, which are regularly supported by verbal and non-verbal means. As part of cooperative tactics, explanations are frequent; flattery, plea, and persuasion are also observed. When counteracting the opponent, the speaker uses a calm tone, a pleading intonation, nonjudgmental proper and common nouns. Among confrontational tactics, reproach is often observed; threats (including appeals to the authorities), orders, declarative denials in case of disagreement, and categorical refusals are less frequent. Their usage is accompanied by an irritated tone, abrupt pronunciation, irony, clichéd constructions (shame on you), imperatives, and a reduction in the volume of statements. At the same time, conflict-generating markers are often mitigated through euphemisms, ellipsis of negative nominations, jokes, replacement of direct criticism of interlocutors with indirect one. At the stage of post-conflict interaction, the communicants return to standard everyday communication without reproaching each other or breaking off relations (breaking off communication with the speaker's ex-spouse and the "marriage wrecker" is an exception). Taking into account the prevalence of cooperative tactics in the informant's discourse, it was concluded that cooperative strategy dominates in her speech behaviour as aiming to prevent confrontation with her interlocutors, to smooth it out, and to reconcile the parties. The identified features of the speaker's speech behaviour are based on the dominants of traditional folk culture (maintaining friendly relations is important for ensuring safe and comfortable coexistence in the village community) and are supported by the individual qualities of the language personality of a cooperative type, characterised by benevolence, tolerance, restraint in the manifestation of emotions, adherence to basic moral norms and etiquette.

\section{References}

1. Murav'eva, N.V. (2002) Rechevye mekhanizmy kommunikativnykh konfliktov [Speech Mechanisms of Communicative Conflicts]. Abstract of Philology Dr. Diss. Moscow. 
2. Tret'yakova, V.S. (2003) Rechevoy konflikt $i$ garmonizatsiya obshcheniya [Speech Conflict and Harmonisation of Communication]. Philology Dr. Diss. Yekaterinburg.

3. Gulakova, I.I. (2004) Kommunikativnye strategii i taktiki rechevogo povedeniya $v$ konfliktnoy situatsii obshcheniya [Communicative Strategies and Tactics of Speech Behavior in a Conflict Communicative Situation]. Abstract of Philology Cand. Diss. Orel.

4. Ivanova, D.V. (2010) Rechevye sposoby preodoleniya konflikta (na materiale russkogo $i$ angliyskogo yazykov) [Speech Methods of Overcoming the Conflict (On the Material of the Russian and English Languages)]. Abstract of Philology Cand. Diss. Saratov.

5. Ershova, V.E. (2013) Rechevoe vzaimodeystvie v usloviyakh konflikta: situatsionnyy podkhod (na materiale tok-shou i teledebatov) [Speech Interaction in Conflict Conditions: A Situational Approach (Based on Talk Shows and Television Debates)]. Abstract of Philology Cand. Diss. Tomsk.

6. Belova, E.V. (2017) Verbal markers of conflict. Vestnik TvGU. Seriya "Filologiya". 2. pp. 157-161. (In Rusian).

7. Komalova, L.R. (2018) Pre-conflict situation reconstruction on the basis of speech communication. Etnopsikholingvistika - Ethnopsycholinguistics. 1. pp. 126-140. (In Russian).

8. Chernykh, Z.V. (2016) Compositional elements of conflict episodes in student communication. Sibirskiy filologicheskiy zhurnal - Siberian Journal of Philology. 2. pp. 177187. (In Russian). DOI: 10.17223/18137083/55/19

9. Sheynov, V.P. (2014) Upravlenie konfliktami [Conflict Management]. Saint Petersburg: Izdatel'stvo "Piter". [Online] Available from: https://bookap.info/book/sheynov_upravlenie_ konfliktami/. (Accessed: 11.03.2020).

10. Antsupov, A.Ya. \& Shipilov, A.I. (2000) Konfliktologiya [Conflictology]. Moscow: YUNITI. [Online]. Available from: http://sdo.mgaps.ru/books/KP1/M11/file/1.pdf. (Accessed: 25.02.2020).

11. Kashapov, M.M. (2003) Teoriya i praktika resheniya konfliktnykh situatsiy [Theory and Practice of Solving Conflict Situations]. Moscow; Yaroslavl: Remder.

12. Ivanova, D.V. (2015) Explanation method in the situation of conflict reconsilition: ecolonguistic approach. Ekologiya yazyka i kommunikativnaya praktika - Ecology of Language and Communicative Practice. 1. pp. 225-231. (In Russian).

13. Ozhegov, S.I. \& Shvedova, N.Yu. (2009) Tolkovyy slovar' russkogo yazyka [Explanatory Dictionary of the Russian language]. 4th ed. Moscow: INFOTEKH.

14. Kazakova, O.A. (2007) Dialektnaya yazykovaya lichnost' dialektonositelya $v$ zhanrovom aspekte [The Dialectal Linguistic Personality of the Dialect Speaker in the Genre Aspect]. Tomsk: Tomsk Polytechnic University.

15. Gorshkova, K.Yu. (2018) Speech genres of reasoned discourse: convincing and persuasion. Izvestiya Volgogradskogo gosudarstvennogo pedagogicheskogo universiteta Izvestia of the Volgograd State Pedagogical University. 5 (128). pp. 108-116.

16. Maslova, A.V. (2014) Realization of harmonious mood of communication in speech of dialect language personality. Ekologiya yazyka $i$ kommunikativnaya praktika - Ecology of Language and Communicative Practice. 1. pp. 143-149. (In Russian).

17. Nichiporovich, E.A. (1998) Kooperativnaya yazykovaya lichnost'v otkrytom kommunikativnom epizode [Cooperative Linguistic Personality in an Open Communicative Episode]. Abstract of Philology Cand. Diss. Moscow.

18. Kushkova, A.N. (2016) Krest'yanskaya ssora: opyt izucheniya derevenskoy povsednevnosti: po materialam evropeyskoy chasti Rossii vtoroy poloviny XIX - nachala XX veka [Peasant Quarrel: An Experience of Studying Rural Everyday Life: Based on Materials from the European Part of Russia in the Second Half of the 19th - Early 20th Centuries]. Saint Petersburg: European University at Saint Petersburg.

19. Rulan, N. (2000) Yuridicheskaya antropologiya [Legal Anthropology]. Moscow: Norma. 